\title{
Hydro-chemical Survey and Quantifying Spatial Variations in Groundwater Quality in Coastal Region of Chennai, Tamilnadu, India - a case study
}

\author{
K. S. Rawat, T. German Amali Jacintha and Sudhir Kumar Singh
}

Received: Augst 2017/ Accepted: June 2018

(C) 2018 Faculty of Geography UGM and The Indonesian Geographers Association

\begin{abstract}
The good quality of groundwater is important for future planning and management. The present study has been undertaken to provide an overview on the status of groundwater quality through physico-chemical parameters namely $\mathrm{pH}$, alkalinity, total hardness, total dissolved solids, chloride, fluoride, nitrate, phosphate and iron through laboratory analysis. Samples have been collected from seven wells located in Chennai coastal region of state Tamilnadu, India. The laboratory-based results shows that the mean value of $\mathrm{pH}$ is 7.29 , alkalinity $(308.57 \mathrm{mg} / \mathrm{l})$, total hardness $(285.71$ $\mathrm{mg} / \mathrm{l})$, chloride $(175.71 \mathrm{mg} / \mathrm{l})$, iron $(0.71 \mathrm{mg} / \mathrm{l})$, nitrate $(13.57 \mathrm{mg} / \mathrm{l})$, phosphorus $(2.71 \mathrm{mg} / \mathrm{l})$ and total dissolved solids $(924 \mathrm{mg} / \mathrm{l})$, respectively. The geo-database water quality parameters were created in Geographical Information System. Further, the kriging a geo-statistical method of interpolation is applied to know the health of groundwater in non-sampled area. This interpolation method has been used to predict spatial distribution physico-chemical parameters in the form of contour. Local planners and policymakers may utilize these results for efficient management of groundwater resources in this area.parameters in the form of contour. Local planners and policy makers may utilize these results for efficient management of groundwater resources in this area.
\end{abstract}

Keywords: Kriging; interpolation; groundwater quality; coastal region; Chennai

Abstrak Kualitas air tanah yang baik sangat penting untuk perencanaan dan pengelolaan di masa mendatang. Penelitian ini dilakukan untuk memberikan gambaran tentang status kualitas air tanah melalui parameter fisika dan kimia air, yaitu pH, alkalinitas, kekerasan total, total padatan terlarut, klorida, fluorida, nitrat, fosfat dan besi melalui analisis laboratorium. Sampel dikumpulkan dari tujuh sumur yang terletak di wilayah pesisir Chennai negara bagian Tamilnadu, India. Hasil laboratorium menunjukkan bahwa nilai rata-rata pH adalah 7,29, alkalinitas (308,57 mg/l), total kekerasan $(285,71$ $\mathrm{mg} / \mathrm{l})$, klorida $(175,71 \mathrm{mg} / \mathrm{l})$, besi $(0,71 \mathrm{mg} / \mathrm{l})$, nitrat $(13,57 \mathrm{mg} / \mathrm{l})$, fosfor $(2,71 \mathrm{mg} / \mathrm{l})$ dan total padatan terlarut $(924 \mathrm{mg} / \mathrm{l})$. Geo-database dari parameter kualitas air kemudian dibuat dalam Sistem Informasi Geografis. Selanjutnya, metode interpolasi geo-statistik kriging diterapkan untuk mengetahui kesehatan air tanah di daerah yang tidak diambil sampelnya. Metode interpolasi ini digunakan untuk memprediksi distribusi spasial parameter fisika-kimia air tanah dalam bentuk kontur. Perencana lokal dan pembuat kebijakan dapat memanfaatkan hasil penelitian ini untuk pengelolaan sumber daya air tanah yang efisien di wilayah kajian.

Kata kunci: Kriging; interpolasi; kualitas air tanah; wilayah pesisir; Chennai

\section{Introduction}

India has diversified geological, climatologically and topographic set up giving rise to divergent groundwater situations in different parts of the country. The quality of groundwater depends on various chemical constituents; their concentration and land use/land cover [Gupta et al., 2009; Singh et al. 2009; Singh et al. 2015; Nemc ${ }^{2}$ ic' -Jurec et al. 2017; Rawat et al.2017; Rawat et al. 2018]. Groundwater contamination and pollution has become a serious concern especially in urban areas due rise in population, excess use and consumerism [Singh et al. 2010; Singh et al. 2017]. Disposal of industrial effluents and untreated sewage

K. S. Rawat and T. German Amali Jacintha

Centre for Remote Sensing and Geo-informatics, Sathyabama University, Chennai - 600 119, Tamil Nadu, India

Sudhir Kumar Singh

K. Banerjee Centre of Atmospheric Ocean Studies, IIDS, Nehru Science Centre, University of Allahabad, Allahabad-211002(U.P.), India Corespondent email: ksr.kishan@gmail.com waste is directly on soil surface and water body. The pollutant directly leaches into groundwater resources and pollute them [Olayinka, 2004; Phiri et al. 2005; Bharose et al. 2013; Rawat et al. 2017]. Removal of groundwater pollutant is complex and very expensive task [Avnish and Saksena, 2010].

Safari [2002] applied kriging technique to estimate spatial distribution of groundwater in Chamchamal plain in west of Iran and reported that suitable techniques of geo-statistics is to estimate one variable depends on variables type and regional factors which influence this and any technique for given region cannot be generalized to others [Rawat et al. 2015]. Istock and Cooper [1998] used kriging method to estimate the presence of heavy metals and reported that it is the best estimator for spatial distribution of lead. Rawat et al. [2015] studied spatial and temporal distribution of nitrate (NO3-) in groundwater by using kriging techniques and reported that kriging technique has showed better accuracy to estimate NO3- concentration. 
Ahmad [2002] used kriging technique to estimate TDS in groundwater and verified accuracy of this technique to prediction of TDS. Rawat et al. [2012b] studied pollution of Mathura district (U.P.) in groundwater for fluoride (F-) concentration. They used kriging technique to estimate F- concentration and to prepare spatial variability map for F-. The present study was planned to carry out groundwater chemical quality mapping of Chennai coast, Tamilnadu, India. Assessment of spatial correlation in hydro-chemical variables is an important tool in the analysis of groundwater chemistry. Present work investigates the spatial correlation of groundwater datasets in the study area using kriging technique [Rawat et al. 2012a; 2012b; Rawat and Singh, 2018]. Spatial assessment of groundwater chemistry is important for revealing the correlation between location and the hydro-chemical variables used. The aim is to describe spatial interpolation techniques for chemical quality mapping of groundwater. The accuracy of interpolation techniques for spatially predicting water and soil properties has been analyzed in several studies. In Chennai coast, water logging and salinity of groundwater become a common problem. The large amount of groundwater in this region is of limited use due to its high salinity. Most of the groundwater in the study area occurs under unconfined aquifer.

Central Chennai coastal region is bordered by Bay of Bengal in the east and dense settlements in the west. It lies between the latitudes $13^{\circ} 1^{\prime}$ to $13^{\circ} 5^{\prime}$ North and longitudes $80^{\circ} 14^{\prime}$ to $80^{\circ} 18^{\prime}$ East in the toposheets no.
$66 \mathrm{C} 7,66 \mathrm{C} 8$ and 66D 1 of Survey of India covering about $9.44 \mathrm{~km} 2$ (Figure 1) and elevation ranges between 6to $10 \mathrm{~m}$ from the MSL. Coovam (North direction) and Adyar rivers (in south direction of study area) Study area is bounded by Bay of Bengal on east, Buckingham canal on west, Coovam river on north and Adyar river on south. Study area come under tropical climate with a range of temperature from 24 to $41^{\circ} \mathrm{C}$. The average annual rainfall of the study area is $1,200 \mathrm{~mm}$ (annual average of 1978-2008). Chennai city receives bulk of its precipitation from North-East monsoon during the period from October to December.

\section{The Methods}

The map of study area was scanned from Survey of India (SOI) toposheets. Boundary map of study area was prepared by on-screen digitization and creating georeferenced boundary map with latitude and longitude at each point. Attribute maps were prepared by adding feature class. This map shows the details of various well numbers (seven bore wells), names and their locations. The study area under consideration was interpolated and attribute maps of study area under consideration were prepared. The attribute maps of the study area were rasterized. The parameters concentration of selected well number of the area under consideration has been interpolated. The stepwise method for preparation of various maps is presented through flowchart (Figure 2). The mask operation was applied for different layers and parameters concentration attribute with area of interest

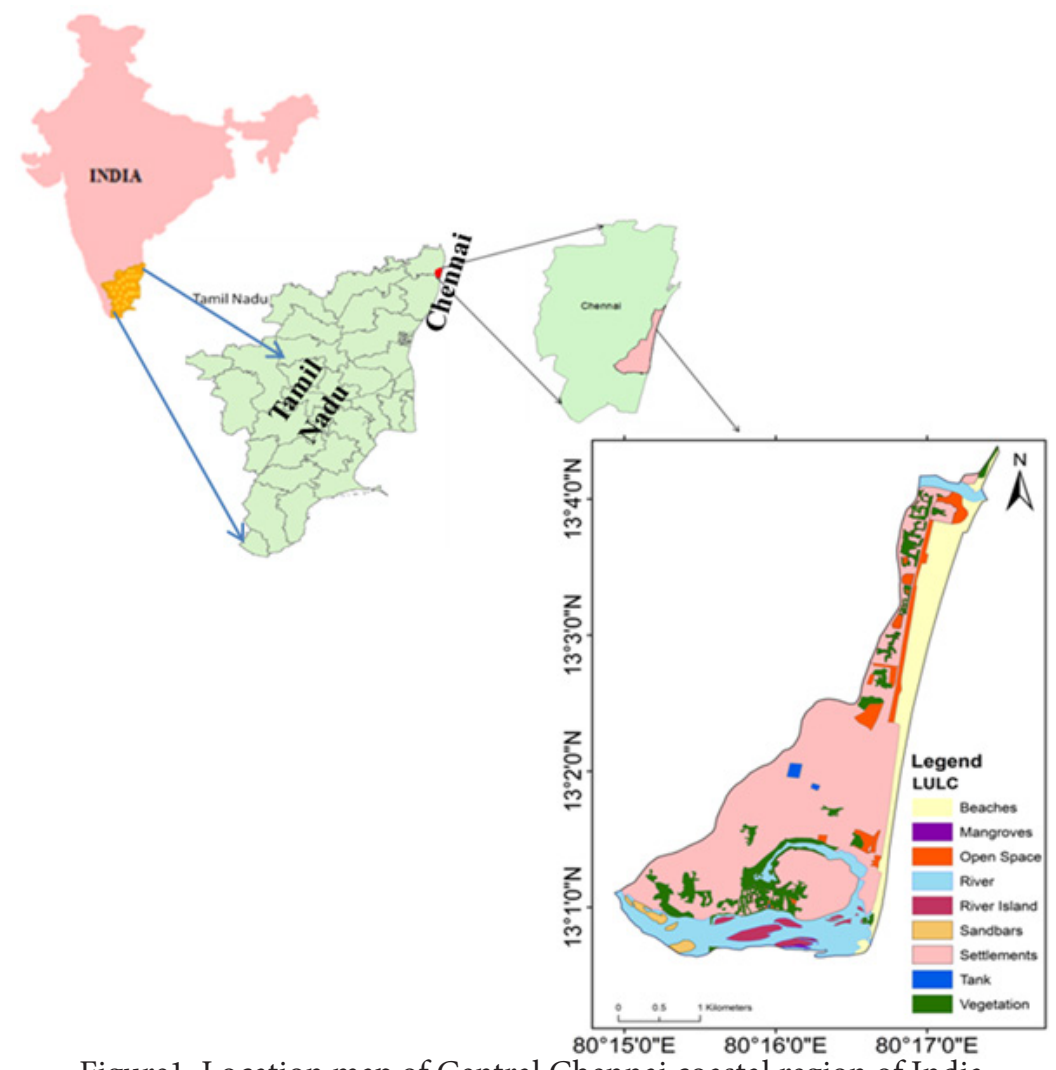

Figure1. Location map of Central Chennai coastal region of India (Study Area) 
(AOI) boundary.

The field data collection and groundwork was conducted in the month of January 2015 with the help of handheld GPS device (Garmin eTrexH), having 15-meter accuracy), to collect the required data for geo-referencing (latitude and longitude) of all the sampling locations. Groundwater samples were collected from phreatic aquifer in clean pre-rinsed 100 ml plastic (polyethylene) bottles. Few drops of toluene were added in each bottle to prevent microbial growth. Standard methods as recommended in APHA [1996] were used for sample collection and laboratory analysis for Total Dissolved Solids (TDS), pH, Total Hardness $(\mathrm{TH})$, anions $\left(\mathrm{Cl}^{-}, \mathrm{F}^{-} \mathrm{NO}^{-}, \mathrm{PO} 43-\right)$ and $\mathrm{Fe} 3+$.

\section{Hydrogeology of the Study Area}

Groundwater of this region occurs under unconfined aquifers. The depth to water table varies from 2.8 meter below ground level (BGL) to $5.0 \mathrm{~m} \mathrm{BGL}$ during pre-monsoon period and from $0.0 \mathrm{~m}$ BGL to 2.0 $\mathrm{m}$ BGL during post-monsoon season [Technical Report Series, 2008]. The general direction of groundwater flow is east to west (Figure. 3a-c). The influent seepage from canal as well as its distributaries has modified the general direction of groundwater flow. The geology of the study area is coastal alluvial.

\section{Geo-statistical approach}

Kriging is a general term describing the geostatistical approach for interpolation at unsampled locations. This method provides less bias in predictions, and hence known as best linear unbiased estimator (BLUE) since the interpolated or Kriged values are computed from equations that minimize the variance of the estimated value. Another advantage of Kriging is that, it presents the possibility of estimation of the interpolation error in the values of the regionalized variable where there are no initial measurements. The spatial dependence is quantified using semi-variogram [Rawat et al. 2012a; 2012b]. The experimental semi- variogram is a graphical representation of the mean square variability between two neighboring points of distance (h) as given in eq. (1).

$$
\gamma(h)=\frac{1}{2 N(h)} \sum_{i=1}^{N(h)}\left[z\left(x_{i}+h\right)-z\left(x_{i}\right)\right]^{2}
$$

eq. 1

Where, $\gamma(\mathrm{h})$ is the semi-variogram expressed as a function of the magnitude of the lag distance or separation vector $h, N(h)$ is the number of observation pairs separated by distance $h$ and $z(x i)$ is the random variable at location xi.

The experimental variogram, $\gamma(\mathrm{h})$ is fitted in theoretical model such as Spherical, Exponential, Linear or Gaussian to determine the three parameter, viz., the nugget $(\mathrm{c} 0)$, the sill (c) and the range (A0). These models are defined as follows [Goovaerts et al. 1999].

$$
\begin{array}{ll}
\text { Spherical model: } & \begin{array}{ll}
\gamma(h)=c_{0}+\left[1.5\left(\frac{h}{A_{0}}\right)-0.5\left(\frac{h}{A_{0}}\right)^{3}\right] & h \leq A_{0} \\
\gamma(h)=c_{0}+c, & h>A_{0}
\end{array}
\end{array}
$$

Exponential model:

$$
\gamma(h)=c 0+c\left[1-\exp \left(-3 \frac{h}{A_{0}}\right)\right]
$$

Gaussian model

$$
\gamma(h)=c 0+c\left[1-\exp \left[-\left(\frac{3 h}{A_{0}}\right)^{2}\right]\right]
$$

Linear model:

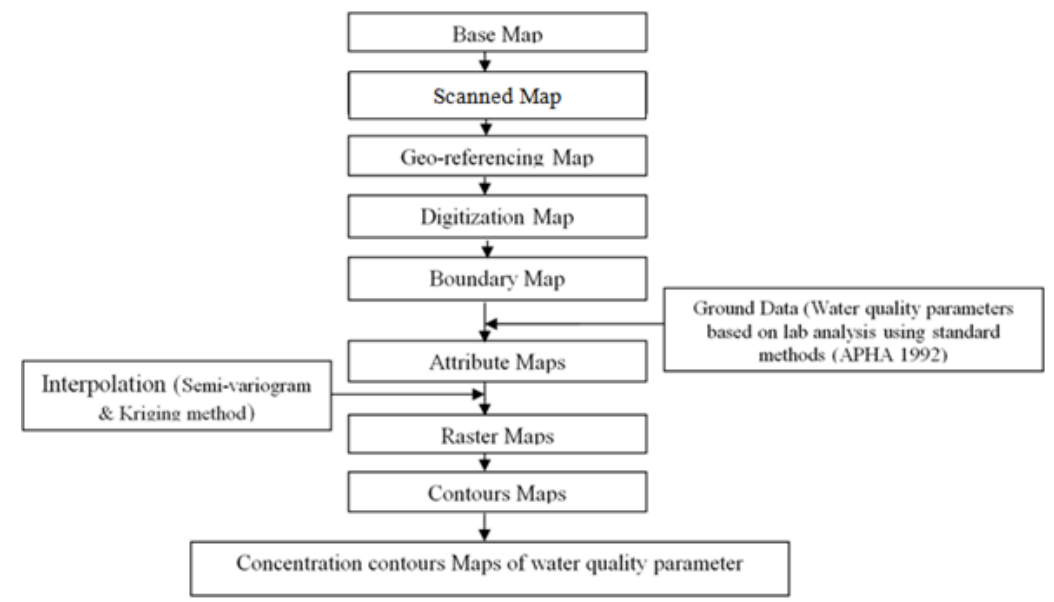

Figure 2. Flow chart of GIS operation for preparation of parameters concentration map 

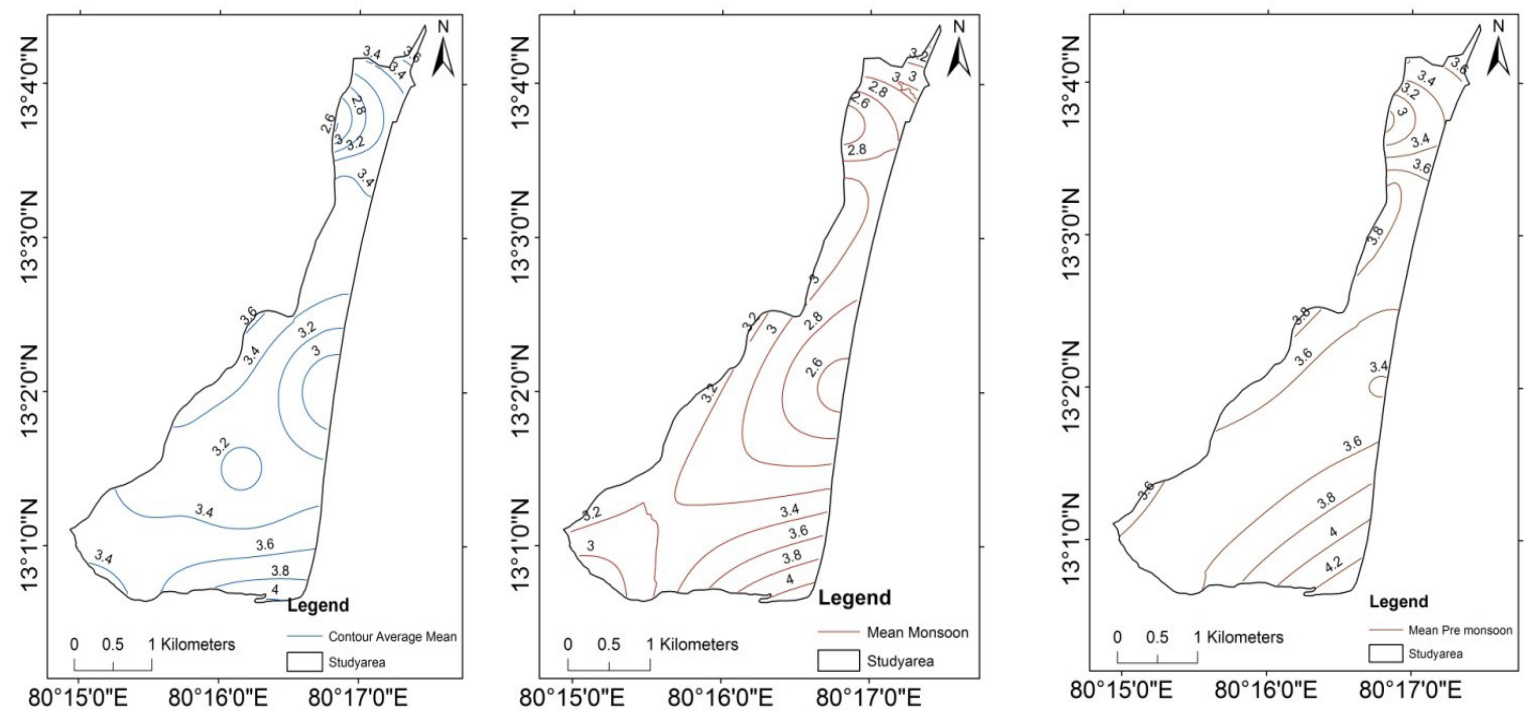

Figure 3. The groundwater flow contour map of the study area (a) mean groundwater flow (b) mean monsoon groundwater flow map and (c) mean pre monsoon groundwater flow map

$$
\gamma(h)=c 0+h\left(\frac{c}{A_{0}}\right)
$$

\section{Results and Discussion}

\section{Physico-chemical characteristics}

Table 1 shows the desirable and maximum permissible limit recommended by, Bureau of Indian Standard [BIS, 1991], World Health Organization [WHO, 1993] and Indian Council of Medical Research (ICMR). Table 2 shows distribution of water quality parameters in groundwater samples of Central Chennai coastal region of India and Table 3 has statistical characterization of groundwater of Central Chennai coastal region. The $\mathrm{pH}$ of all the groundwater samples was about neutral, the range being 7.0 to 7.5 . The total alkalinity value of water is important in calculating the dose of alum and biocides in water [Trivedy and Goel, 1986; Singh et al. 2013; Singh et al. 2015]. Total alkalinity value varied from 240 to $410 \mathrm{mg} / \mathrm{l}$. All the water samples have total alkalinity value within the permissible limit of 200 to $600 \mathrm{mg} / \mathrm{l}$ according to BIS.

Total Hardness is essential parameter in decreasing the toxic effect of poisonous element. The hardness was found to be in the range of $170 \mathrm{mg} / \mathrm{l}$ (sample no. 6) to $470 \mathrm{mg} / \mathrm{l}$ (sample no. 7). Almost all samples point of the study area, the hardness is equal to WHO, BIS and ICMR prescribed desirable limit (300 mg/l). According to Durfor and Becker's [1964] classification of TH (i.e. 0-60, soft; 61-120, moderately hard; 121-180, hard; and >180 very hard). Majority of samples lies in range of 180 , very hard $(\mathrm{TH}>180)$ category, such very hard groundwater may raise the risk of calcification of arteries, urinary concretions, diseases of kidney or bladder or stomach disorder [Kumar et al. 2011].
TDS signify the inorganic load to any water body. Their values in the study area are more than highest desirable limit of $500 \mathrm{mg} / \mathrm{l}$ [ISI, 1983] for drinking purpose, which indicates higher electrical conductivity (EC) may be attributed to high salinity and high mineral content at the sampling points. The higher EC of the water samples is the result of ion exchange and solubilization in the aquifer [Sánchez-Pérez, and Trémolières, 2003].

Chloride $(\mathrm{Cl}-)$ is major inorganic components, which may deteriorate the quality of groundwater for drinking purpose [Gautam et al. 2015; Gautam et al. 2016; Singh et al. 2015; Thakur et al. 2015]. Clconcentration in groundwater ranged from 100 (samples no. 3 and 6) to $260 \mathrm{mg} / \mathrm{l}$ (samples no. 7) and samples no. 5 contained higher concentration than maximum permissible limits $(250 \mathrm{mg} / \mathrm{l})$ for drinking water. $\mathrm{Cl}-$ concentrations higher than $200 \mathrm{mg} / \mathrm{l}$ are considered to be at risk for human health with unpleasant taste of water.

In our study area, all samples are under WHO limit. Low concentration (approximately $0.5 \mathrm{mg} / \mathrm{l}$ ) provides protection against dental caries. During analysis only sample no. 2 has $1.5 \mathrm{mg} / \mathrm{l}$ values and all other samples are under acceptable limit of WHO, BIS and ICMR. Phosphorus (PO43-) is one of the key elements necessary for growth of plants and animals. Phosphorus in elemental form is very toxic and is subject to bioaccumulation. Phosphate formed from this element. Phosphate exists in three forms, i.e Orthophosphate, met-pho sulfate, and organically bound phosphate. Each compound contains phosphorus in a different chemical formula orthoform are produced by natural processes and are found in sewage [Singh et al. 2012; Gautam et al. 2013; Kumar et al. 2015]. Elevated of PO43-in range of 2 to $5 \mathrm{mg} / \mathrm{l}$, in study area's groundwater leaching from 
Table 1. Maximum permissible limit of chemical parameters and their comparison with the WHO and Indian standards (BIS and ICMR) for drinking water

\begin{tabular}{lrrr}
\hline \multicolumn{4}{c}{ Maximum permissible limits } \\
\hline \multicolumn{1}{c}{ Parameters } & WHO-1993 & BIS-1991 & \multicolumn{1}{c}{ ICMR } \\
\hline pH & $7.0-8.5$ & $6.5-8.5$ & $7.0-8.5$ \\
Alkalinity & -- & $200-600$ & \\
TH & 300 & 300 & 300 \\
TDS & 500 & 500 & - \\
Cl & 200 & 250 & 200 \\
F & 1.5 & 1.5 & 1.5 \\
NO3- & 50 & $45-100$ & 100 \\
PO43- & 0.1 & &
\end{tabular}

Table 2. Distribution of water quality parameters in groundwater samples of Central Chennai coastal region of India

\begin{tabular}{lrrrrrrr}
\hline Parameters & Well No. 1 & Well No. 2 & Well No. 3 & Well No. 4 & Well No. 5 & Well No. 6 & Well No.7 \\
\hline pH & 7.5 & 7.0 & 7.5 & 7.0 & 7.0 & 7.5 & 7.5 \\
Alkalinity & 320.0 & 280.0 & 260.0 & 410.0 & 300.0 & 240.0 & 350.0 \\
TH & 270.0 & 290.0 & 190.0 & 300.0 & 310.0 & 170.0 & 470.0 \\
TDS & 912.00 & 888.00 & 660.00 & 1164.00 & 948.00 & 612.00 & 1284.00 \\
Cl & 170.0 & 170.0 & 100.0 & 260.0 & 180.0 & 100.0 & 250.0 \\
F & 00 & 00 & 00 & 0.30 & 0.50 & 00 & 1.50 \\
NO3 & 20.00 & 10.00 & 20.00 & 25.00 & 0.00 & 10.00 & 10.00 \\
PO4 & 3.00 & 2.00 & 5.00 & 2.00 & 3.00 & 2.00 & 2.00 \\
\hline
\end{tabular}

Table 3. Statistical characterization of groundwater of Central Chennai coastal region

\begin{tabular}{|c|c|c|c|c|c|c|c|c|}
\hline Test & $\mathrm{pH}$ & $\begin{array}{c}\text { Alkalinity } \\
(\mathrm{mg} / \mathrm{l})\end{array}$ & $\mathrm{TH}(\mathrm{mg} / \mathrm{l})$ & $\begin{array}{c}\mathrm{Cl}- \\
(\mathrm{mg} / \mathrm{l})\end{array}$ & $\begin{array}{c}\mathrm{F}- \\
(\mathrm{mg} / \mathrm{l})\end{array}$ & $\begin{array}{l}\text { NO3- } \\
(\mathrm{mg} / \mathrm{l})\end{array}$ & $\begin{array}{l}\mathrm{PO} 43- \\
(\mathrm{mg} / \mathrm{l})\end{array}$ & $\begin{array}{l}\text { TDS } \\
(\mathrm{mg} / \mathrm{l})\end{array}$ \\
\hline Mean & 7.29 & 308.57 & 285.71 & 175.71 & 0.71 & 13.57 & 2.71 & 924.00 \\
\hline $\begin{array}{l}\text { Standard } \\
\text { Error }\end{array}$ & 0.10 & 21.87 & 37.02 & 23.99 & 0.18 & 3.22 & 0.42 & 92.10 \\
\hline Median & 7.5 & 300 & 290 & 170 & 0.5 & 10 & 2 & 912 \\
\hline $\begin{array}{l}\text { Standard } \\
\text { Deviation }\end{array}$ & 0.27 & 57.86 & 97.96 & 63.47 & 0.49 & 8.52 & 1.11 & 243.67 \\
\hline Range & 0.5 & 170 & 300 & 160 & 1.5 & 25 & 3 & 672 \\
\hline Minimum & 7 & 240 & 170 & 100 & 0 & 0 & 2 & 612 \\
\hline Maximum & 7.5 & 410 & 470 & 260 & 1.5 & 25 & 5 & 1284 \\
\hline
\end{tabular}

soils or weathering, rock, deposition of atmospheric volcanic particles, septic and sewage treatment system discharges in communities with PO43- water supplies, liquid waste from industrial sources, sandstone and mudstone aquifer system on study area are largely a result of high PO43- in groundwater, and all sample are above WHO specification limit $(0.1 \mathrm{mg} / \mathrm{l})$. It is evident that this process may be responsible for elevated PO43levels in groundwater around study area.

\section{Interpretation of Contours maps}

Distribution of alkalinity, $\mathrm{pH}, \mathrm{TH}, \mathrm{TDS}, \mathrm{Cl}^{-}, \mathrm{F}^{-}$, $\mathrm{NO}^{-}$and PO43- for the year 2015 is presented in Fig. $4 \mathrm{a}$ to $12 \mathrm{~b}$. Central part of the contours maps (Fig. 4a and $4 \mathrm{~b}$ ) shows only normal values of $\mathrm{pH}$ (7.1 to 7.3) while the upper part shows slightly higher values of $\mathrm{pH}$ (7.45), upper part of Buckingam Canal). Spatial distribution of alkalinity for the period 2015 is presented in Figure 5a and $5 \mathrm{~b}$. In the middle part of the study area especially towards the eastern direction, the concentration of alkalinity is found to be higher than the other parts 

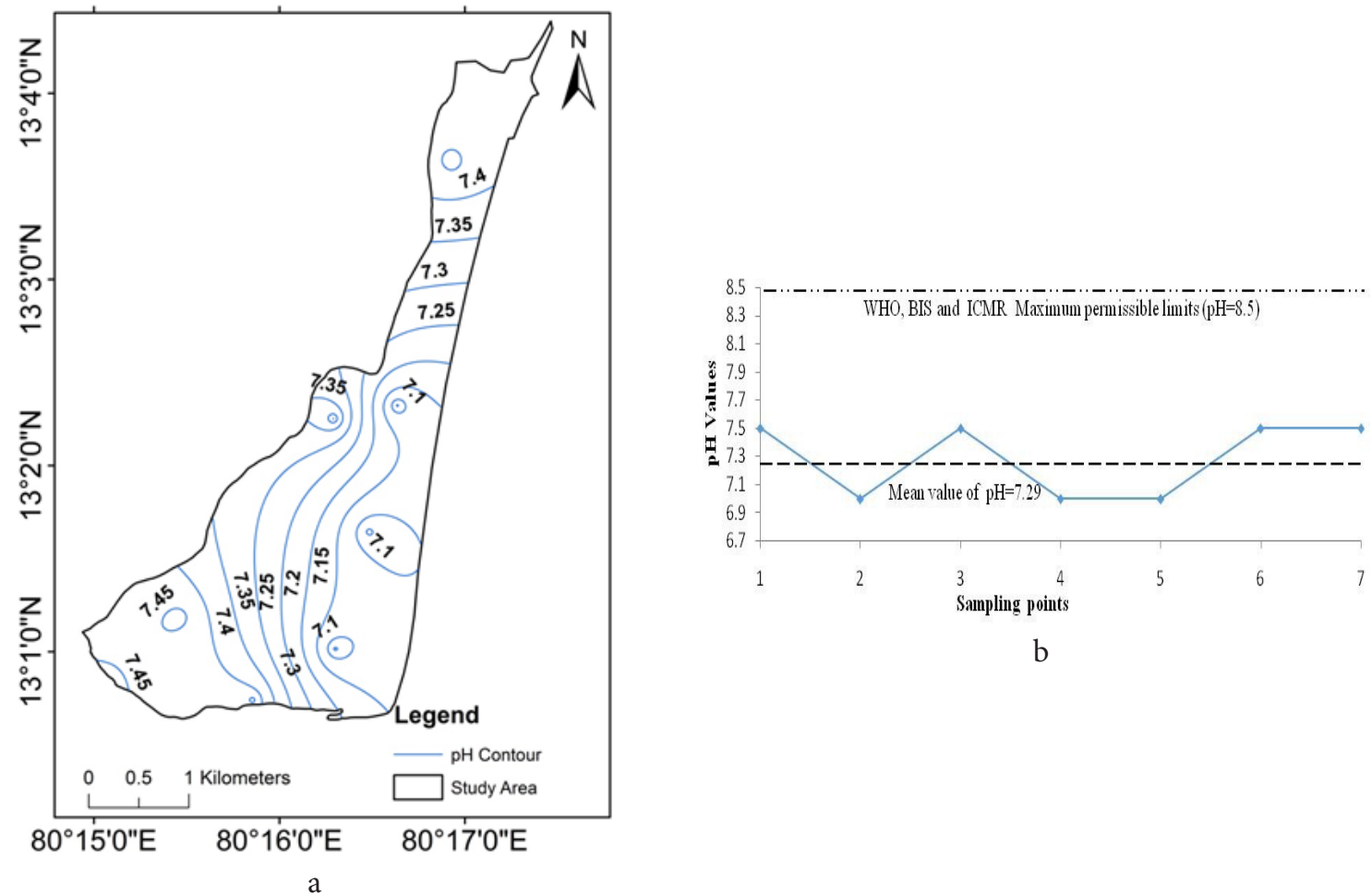

b

Figure 4a. $\mathrm{pH}$ contours and spatial distribution in groundwater in study area, 4bVariation of $\mathrm{pH}$ from standard permissible limits in study area
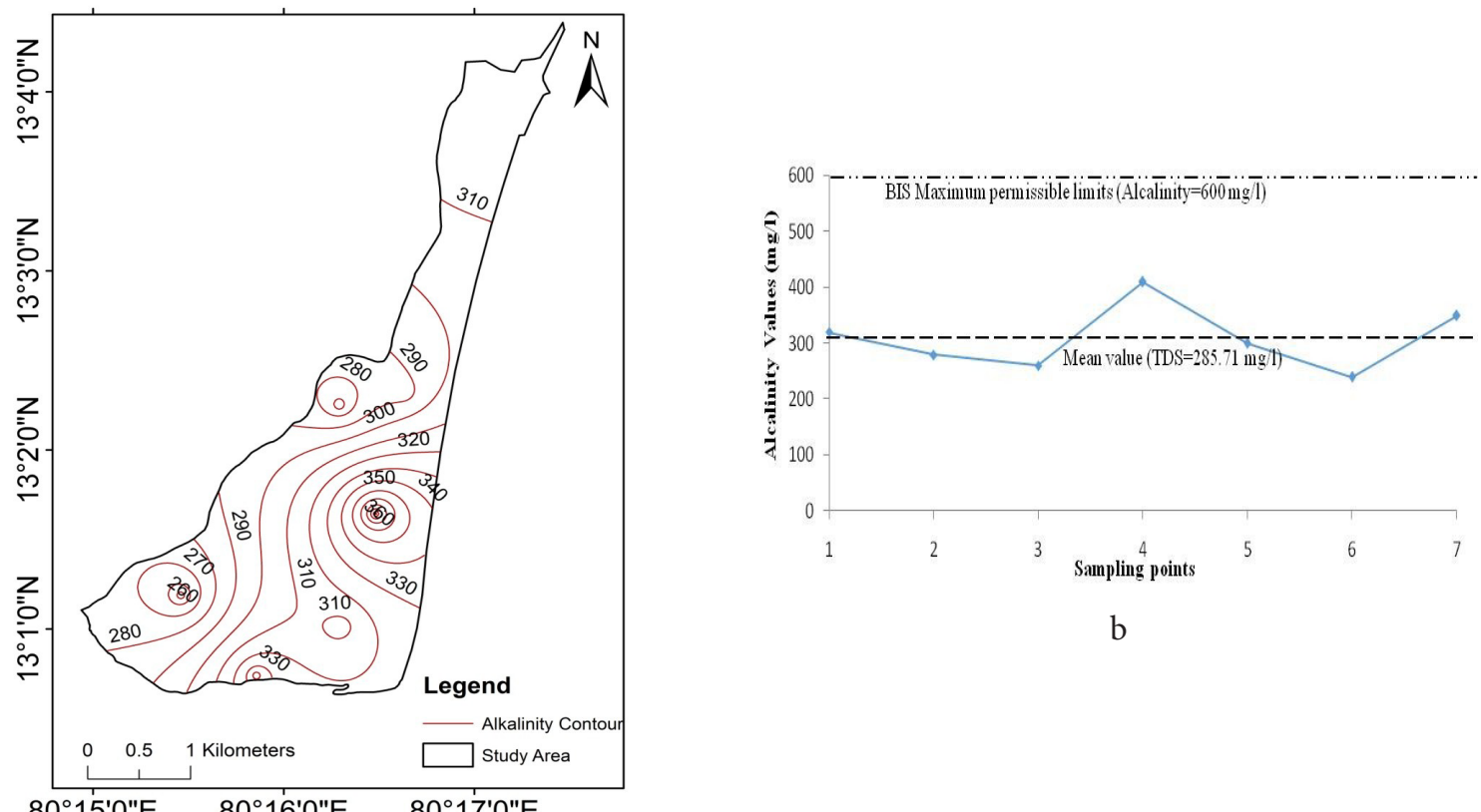

$\mathrm{b}$

Figure 5a. Alkalinity contours and spatial distribution in groundwater in study area, Figure. 5b Variation of Alkalinity from standard permissible limits in study area 

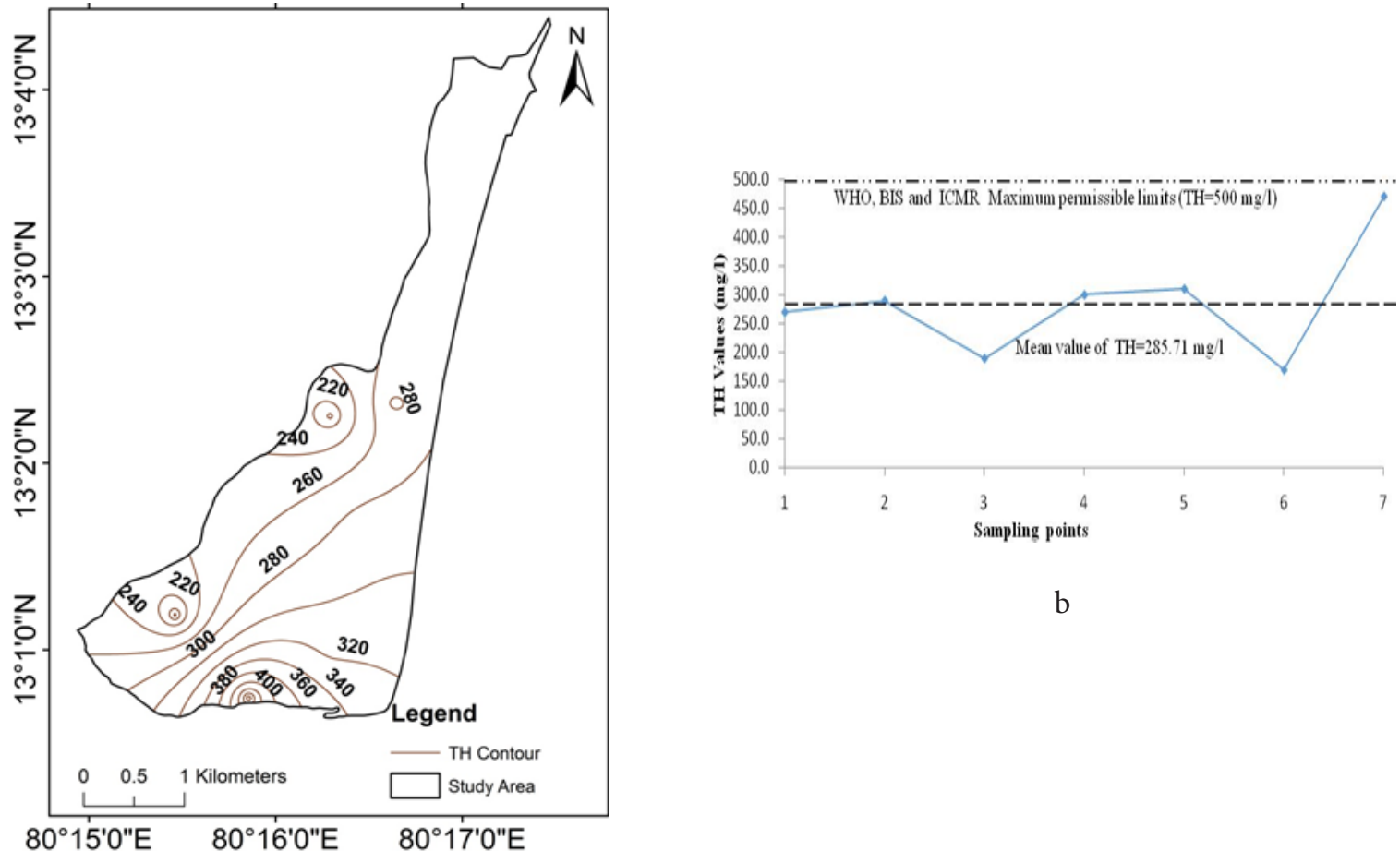

b

Figure 6a. Total hardness (TH) contours and spatial distribution in groundwater in study area, 6bVariation of total hardness $(\mathrm{TH})$ from standard permissible limit
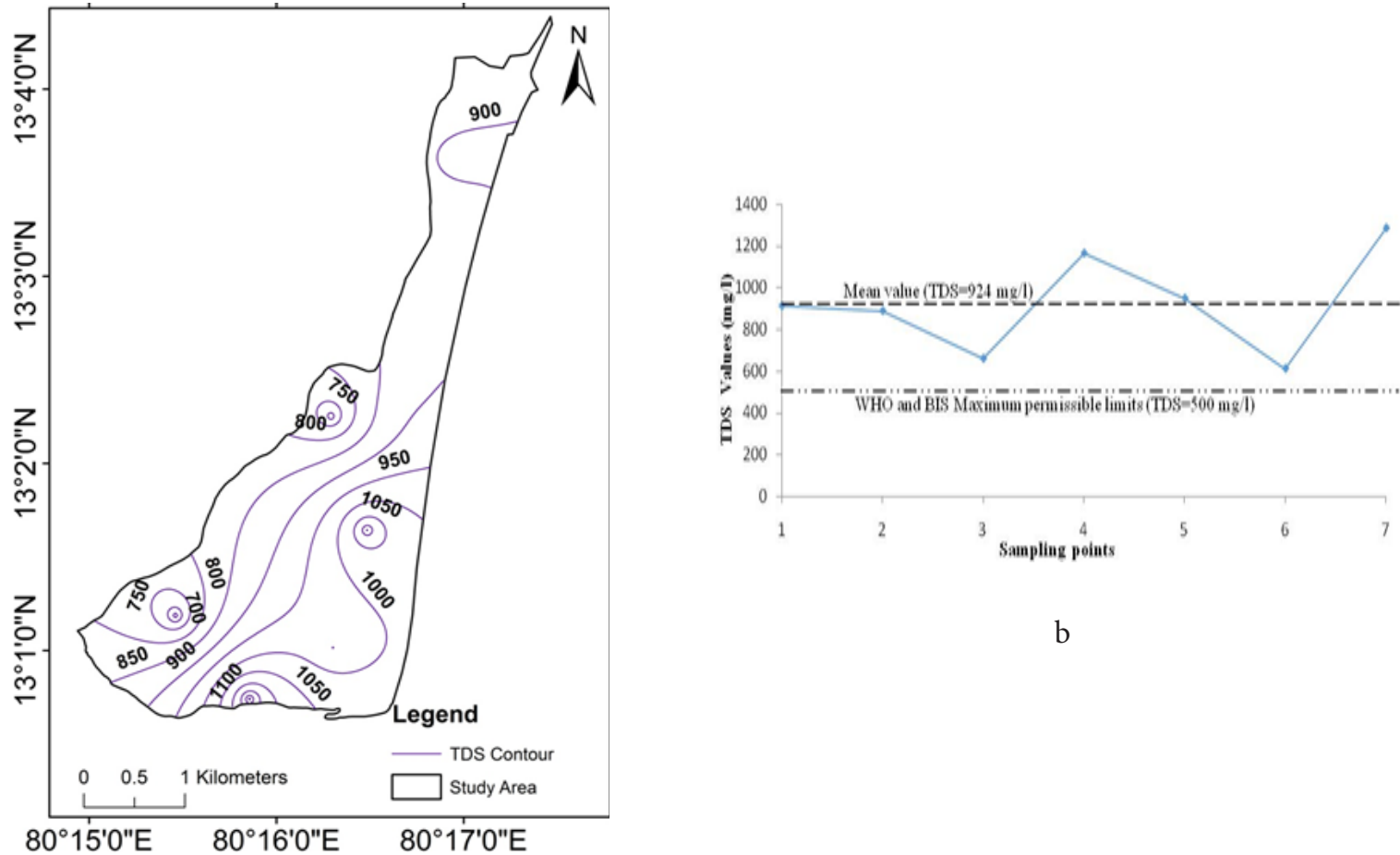

b

Figure 7a. Total dissolved salt (TDS) contours and spatial distribution in groundwater in the study area, 7b Deviation of total dissolved salt (TDS) from standard permissible limits in the study area 

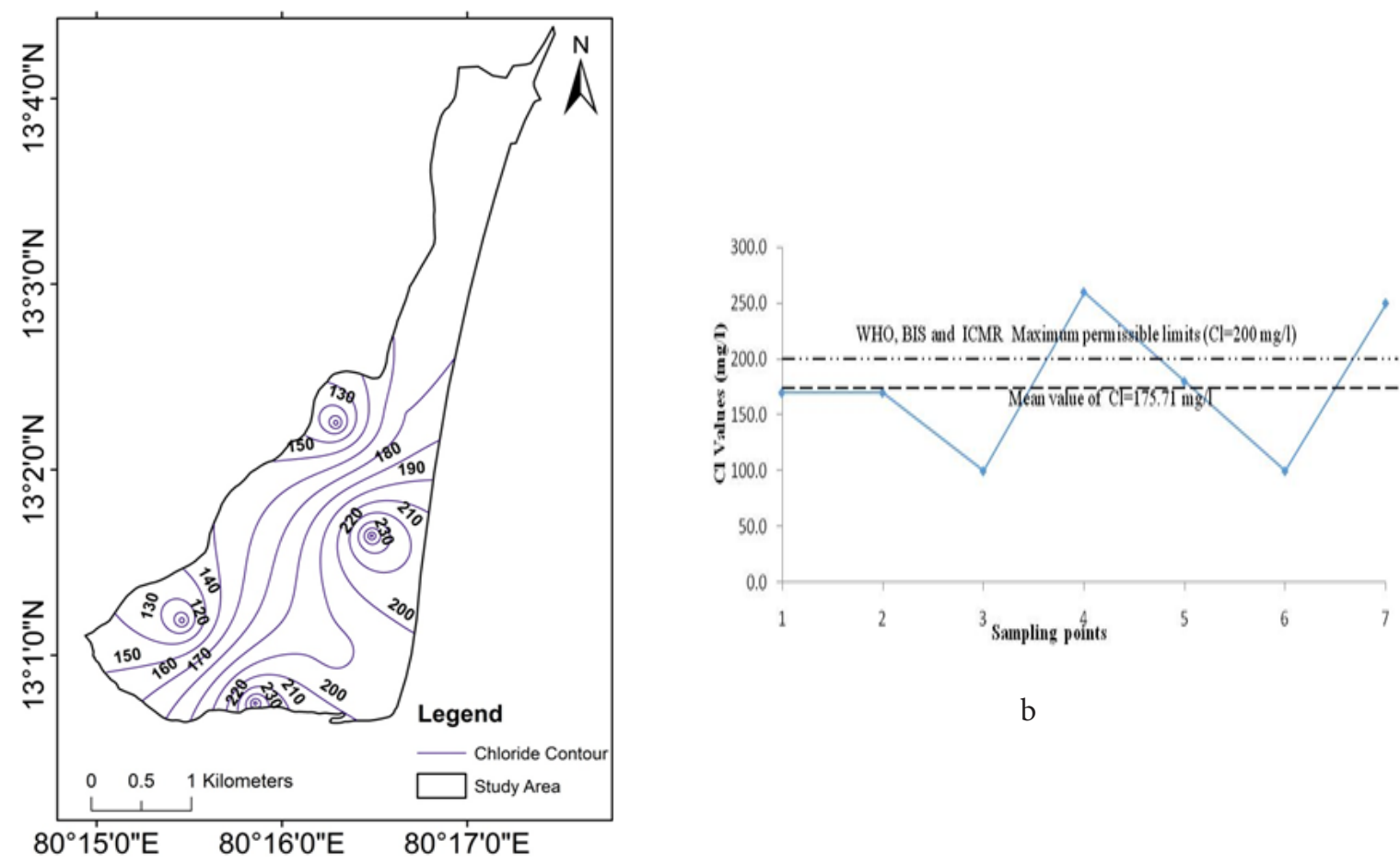

b

a

Figure 8a. Chloride ( $\mathrm{Cl}-$ ) contours and spatial distribution in groundwater in the study area, $8 \mathrm{~b}$ Deviation of Chloride $(\mathrm{Cl}-)$ from standard permissible limits in the study area
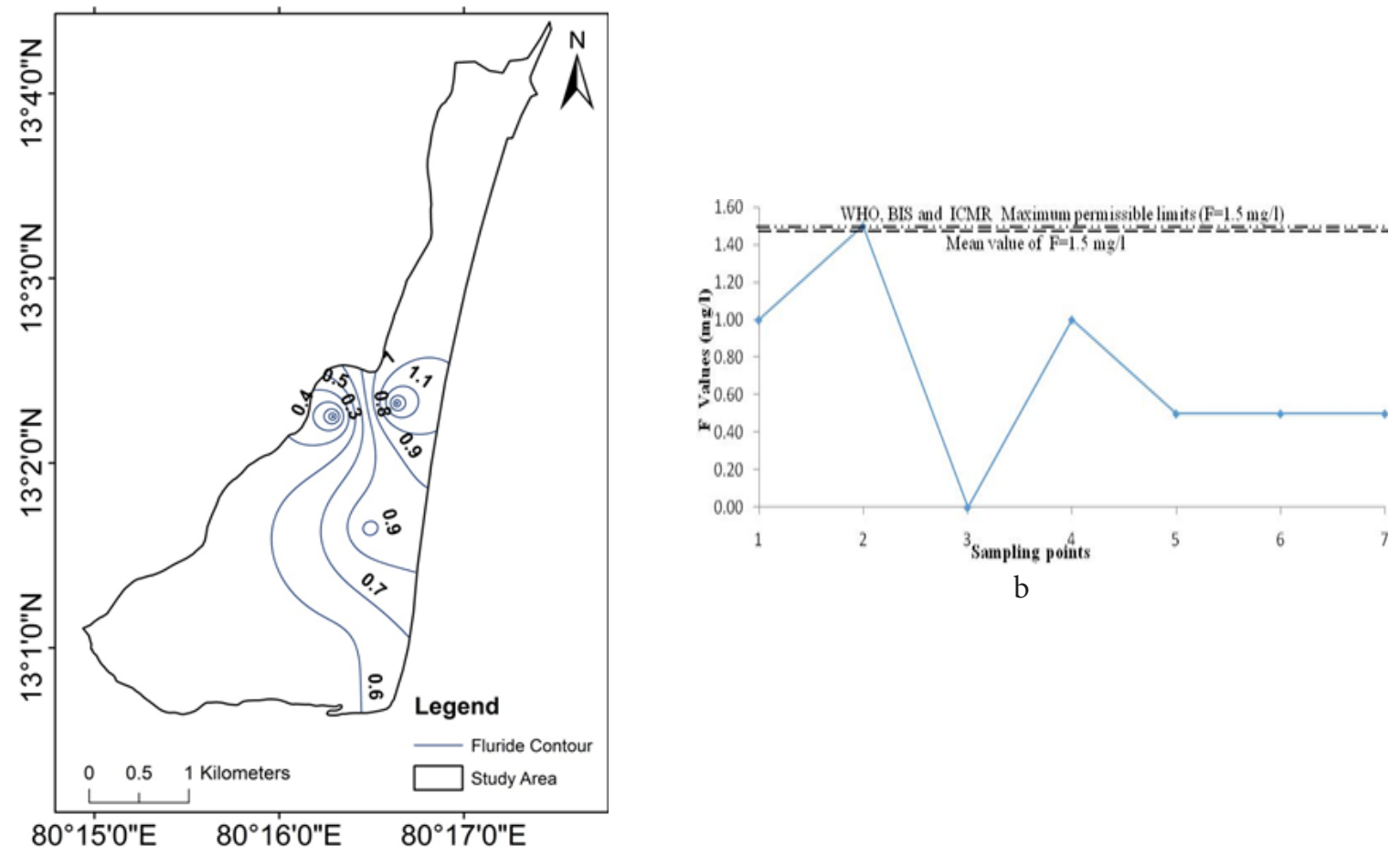

$\mathrm{b}$

Figure 9a. Fluoride (F-) contours and spatial distribution in groundwater in study area, 9b Deviation of Fluoride $(\mathrm{F}-)$ from standard permissible limits in study area 

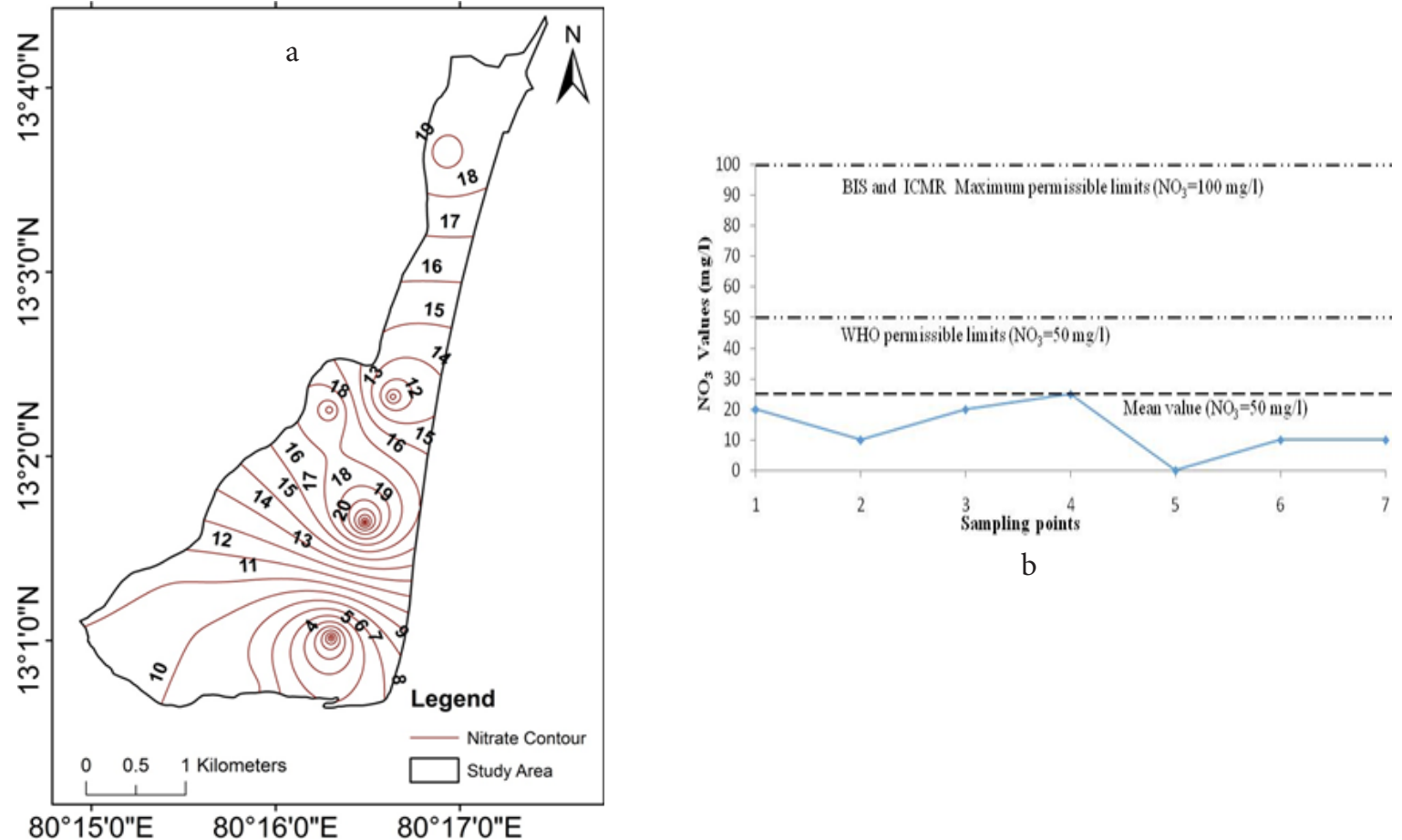

b

Figure 10a. Nitrate (NO3-) contours and spatial distribution in groundwater in study area, 10b Deviation of Nitrate (NO3-) from standard permissible limits in the study area
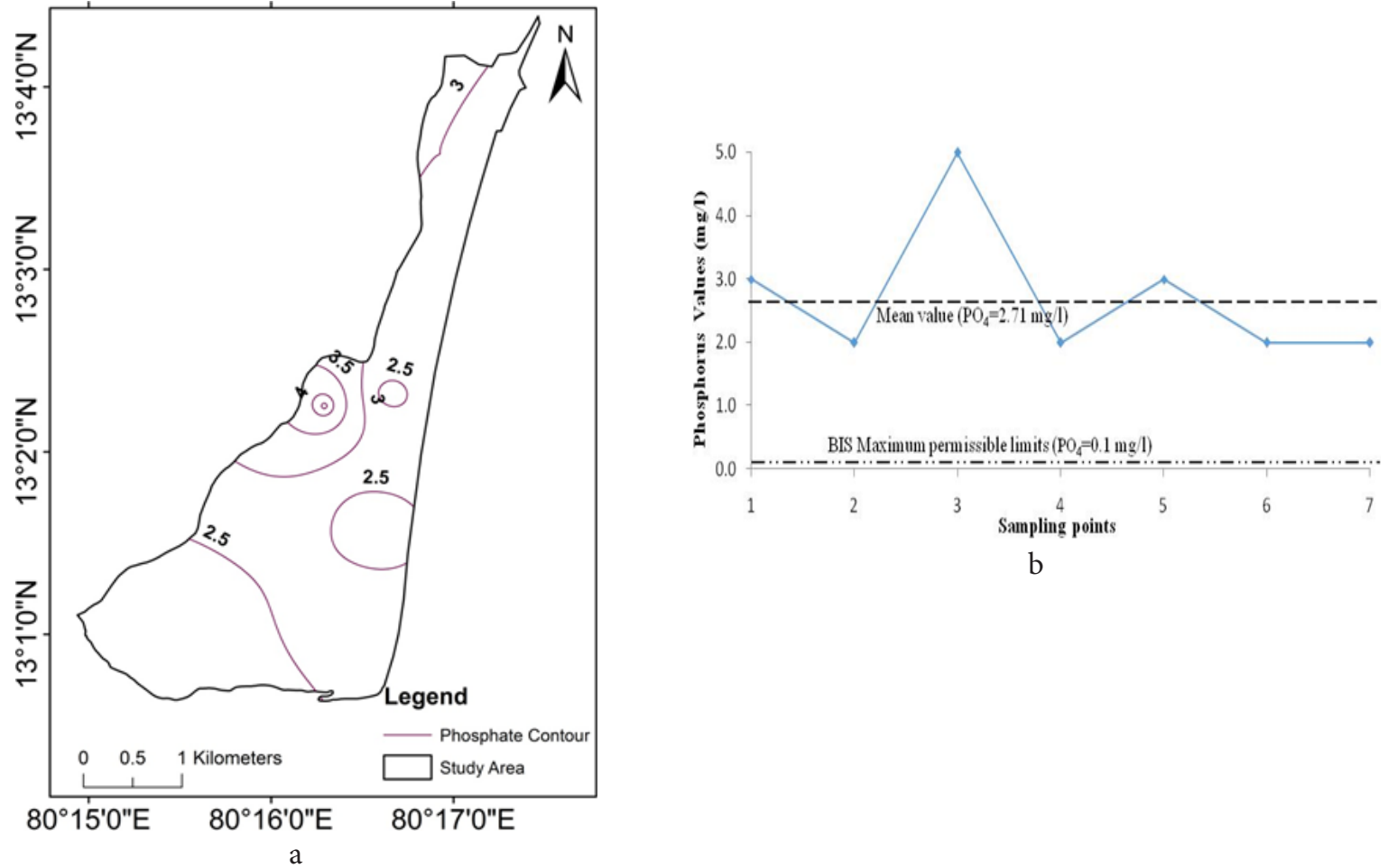

b

Figure 11a. Phosphorus (PO43-) contours and spatial distribution in groundwater in study area, 11b Deviation of Phosphorus (PO43-) from standard per 


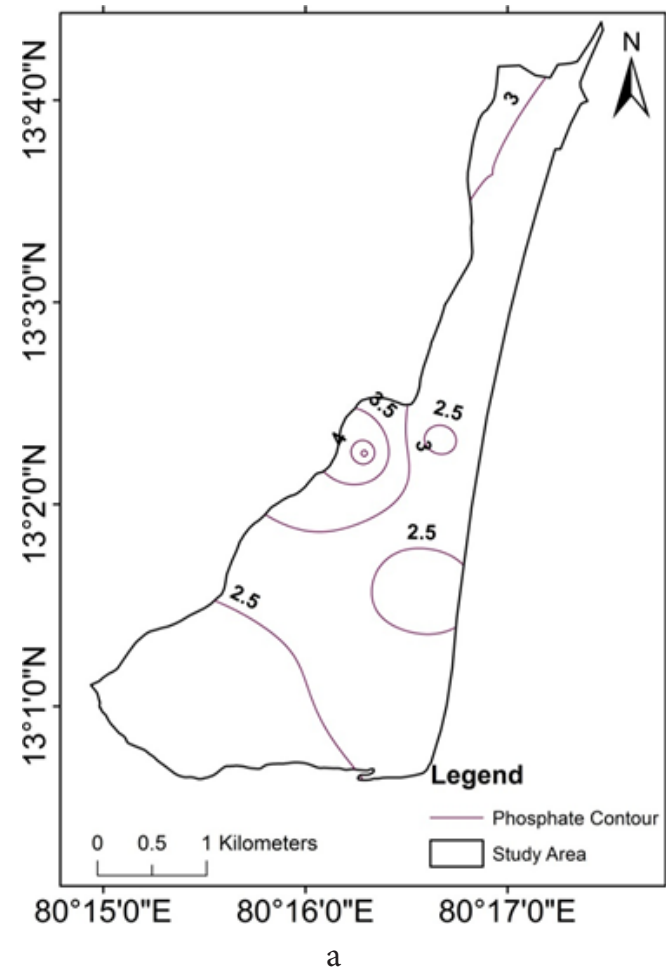

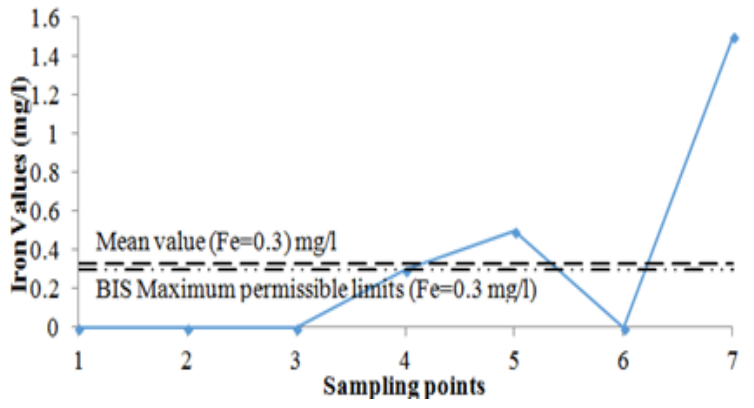

b

Figure.12a Iron $(\mathrm{Fe})$ contours and spatial distribution in groundwater in study area, 12b Deviation of Iron (Fe) from standard permissible limits in the study area

of the region. TH contour maps for the year 2015 are presented in Figure. 6a and 6b. Middle part of the study area show values in the range of 280 to $300 \mathrm{mg} / \mathrm{l}$ contour region. The maximum total dissolved solids TDS concentration in the groundwater of the region is 1150 $\mathrm{mg} / \mathrm{l}$. It was also observed that most of area around well no. 2 is within the safe limit $(900 \mathrm{mg} / \mathrm{l}$, Figure $7 \mathrm{a}$ and $7 b$ ). It reflects the level of minerals (such as carbonates, bicarbonates, chlorides, sulphate, phosphate, silica, calcium, magnesium, sodium, and potassium) that are present in water samples in dissolved form. The TDS values ranged between 612 to $1284 \mathrm{mg} / \mathrm{l}$. Chloride $\left(\mathrm{Cl}^{-}\right)$ concentration has been presented in Figure $8 \mathrm{a}$ and $8 \mathrm{~b}$. Central part of map shows only normal values ranges of $\mathrm{Cl}^{-}(170 \mathrm{mg} / \mathrm{l}$ while around the well no. 4 shows variation in $\mathrm{Cl}^{-}$values (210 to $240 \mathrm{mg} / \mathrm{l}$ ). Variability in the values of $\mathrm{F}$ - for the year 2015 and its distribution according to the average chemical composition is presented in Fig. $9 \mathrm{a}$ and 9b. Average value of NO3- (Figure 10a and 10b) is randomly distribution over the study area and higher values were observed at upper left side but lower values at lower region. Contour and graph (Figure 11a and 11b) shows PO43-concentration from 2 to $5 \mathrm{mg} / \mathrm{l}$. All study area under of high values of PO43-and all study area is above the limit prescribed by WHO $(0.1 \mathrm{mg} / \mathrm{l})$. It shows that study area is contaminated with elevated PO43- levels in groundwater. Figure.12a shows Iron (Fe) contours and spatial distribution in groundwater in study area and Fig. 12b shows deviation of Iron (Fe) from standard permissible limits in the study area.

\section{Statistical Analysis}

Correlation matrices among various water quality parameters were studied and it was noticed that most of the parameters bear statistically significant correlation and indicates close association among them self (Table 4). Alkalinity shows a very strong positive relationship with Cl- $(\mathrm{r}=0.93)$ but weakly related with F- $(\mathrm{r}=0.31)$. Alkalinity shows a strong correlation with TDS and TH respectively with the value of correlation coefficient 0.88 and 0.62. TDS also shows significant correlation with $\mathrm{TH}$ $(\mathrm{r}=0.98)$. While $\mathrm{Cl}$ - having highly significant correlation with $\mathrm{TH}(0.83)$ have only moderate correlation with $\mathrm{pH}(\mathrm{r}=0.41)$. A fairly good negative correlation of PO43- with F- ( $r=-0.64)$ reveals that PO43- is not only a product of weathering but some other sources may also be contributing PO43- to groundwater. $100 \%$ of the samples have PO43- concentrations exceeding the threshold value of $0.1 \mathrm{mg} / \mathrm{l}$ (Table 4 ) of anthropogenic source. Based on correlation matrix, TH, TDS and Clare suggested as a marker of groundwater quality of study area, prior to its use for domestic and drinking purpose.

Alkalinity is primarily due to carbonate, bicarbonate and hydroxide contents [Singh et al. 2013; Singh et al. 2015; Thakur et al. 2015; Jacintha et al. 2016, Rawat and Singh, 2018]. It is used in the interpretations and control of water and wastewater processes. Almost all natural waters alkalinity is produced by the dissolved carbon dioxide species, bicarbonate and carbonate [Srivastava et al. 2013; Singh et al. 2013; Singh et al. 2012]. Typically expressed of $\mathrm{CaCO} 3$, various ionic species that contribute to the alkalinity include 
hydroxide, carbonates, bicarbonates and organic acids [Gautam et al. 2015; Gautam et al. 2016]. These factors are characteristic sources of water and many natural processes take place at any place.

Higher concentrations of TDS decrease the palatability and may cause gastro-intestinal disorder in human and may also have laxative effect particularly upon transits [Yadav and Khera, 1993].

High consumption of $\mathrm{Cl}-$ may be crucial for the development of essential hypertension, risk for stroke, left ventricular hypertrophy, osteoporosis, renal stones and asthma [McCarthy 2004]. Considering that Clrich minerals are not found in the study area, high $\mathrm{Cl}$ - content of groundwater is likely to originate from pollution sources such as domestic effluents, and septic tanks, and from natural sources such as rainfall, the dissolution of fluid inclusions.

Fears have been expressed that high nitrate (NO3-), levels in drinking water may cause methamoglobinaemia or well water cyanosis, in bottle-fed infants. Circumstantial proof has also been postulated that amines and nitrite react in the human body to form carcinogenic nitrosamines, the nitrite resulting from the reduction of ingested nitrate [Evans et al. 1993]. Whenever nitrate limits in water are exceeded, it is recommended that infants up to the age of one year be supplied with low-nitrate water from other sources. The World Health Organization (WHO) 1993 has established maximum permissible limits for nitrates in water used for drinking purposes at $45 \mathrm{mg} / \mathrm{l}$. High nitrate levels found in drinking water have been proven to be the cause for numerous health conditions across the world [Buluse and Pandey, 1990].

Nitrate can be persistent in aquifers where denitrification is reduced. Higher nitrate levels in groundwater are generated by adjacent land use; nitrate can be an effective tracer of groundwater flow [Johanssion, 1988; Singh et al. 2013a; Bharose et al. 2013].

Enrichment of minor ions $\mathrm{F}$ (Fluoride) in intruding saline water and depletion in K (Potassium) may be due to interaction of groundwater with sediments (Lloyd and Heathcote, 1985; Rawat et al. 2012a). Elevated of fluoride (Min=0 and $\mathrm{Max}=1.5 \mathrm{mg} / \mathrm{l}$; Table 3 ) status in study area's groundwater leaching from soils or weathering, rock, deposition of atmospheric volcanic particles, septic and sewage treatment system discharges in communities with fluoridated water supplies, liquid waste from industrial sources, sandstone and mudstone aquifer system on study area are largely a result of base-exchange softening. It is evident that this process may be responsible for elevated fluoride levels in groundwater around study area. According to WHO [1993] and Indian standard drinking water specification [1991] the maximum permissible limit of fluoride in drinking water is $1.5 \mathrm{mg} / \mathrm{l}$ and highest desirable limit is $1.0 \mathrm{mg} / \mathrm{l}$. Fluoride concentrations above $1.5 \mathrm{mg} / \mathrm{l}$ in drinking water cause dental fluorosis and much higher concentration skeletal fluorosis [Thakur et al. 2013; Singh et a. 2013b; Gautam et al. 2013].

\section{Conclusion}

The groundwater of studied area is used for domestic and other purposes. A large number of factors and geological conditions influence the groundwater quality. The physico-chemical parameters (TH, pH and alkalinity) of all bore well at study area for January 2015 are within desirable limit/permissible limit prescribed by WHO and BIS except TDS. It has been concluded that bore wells under the study area is not fit for drinking purposes yet. It needs treatment to minimize the contamination especially PO43- and TDS contents. To reduce the contaminations of bore wells water at study area, the values of correlation coefficients and their significance level will help in selecting the proper experimental methods used for treatment of water. To increase awareness among the people to maintain the groundwater at its good quality, the present study may prove to be useful in achieving this goal. The study has demonstrated the utility of GIS technology along with laboratory analysis in evaluation and geospatial variability mapping of groundwater quality.

\section{References}

Avnish, K. V. and D. N. Saksena (2010). Assessment of water quality and pollution status of Kalpi (Morar) River, Gwalior, Madhya Pradesh: with special reference to Conservation and Management plan.

Ahmed S. (2002). Groundwater monitoring network design: Application of Geostatistics with a few Case studies from a granitic aquifer in a semiarid region, Groundwater Hydrology (eds. Sherif, M.M., V.P. Singh and M. Al-Rashed), Balkema, Tokyo, Japan, 2002, vol. 2, pp. 37-57.

BIS. "Indian Standard specification for drinking water" B.S. 10500, 1991.

Barca, E. and G. Passarella (2007). Spatial evaluation of the risk of groundwater quality degradation, A comparison between disjunctive kriging and geostatistical simulation", Environmental Monitoring and Assessment, 38, 25-39.

Bharose R, Singh SK, Srivastava PK. (2013). Heavy metals pollution in soil-water-vegetation continuum irrigated with ground water and untreated sewage 1. Bull Environ Sci Res. 2:1-8.

CGWB (2008). District groundwater brochure, Chennai, Tamil Nadu. Technical report series.

Durfor, C. M., Becker. E, 1964. Public water supply of the ten largest cities in the United States, US. Geal. Sur. Water Supply paper 1812, 364

Evans, D., Moxon, I.R. and J.H.C. Thomas (1993). Groundwater nitratecontaminants from the old Chalford Nitrate Sensitive Area, WestOxfordshire. J. Inst. Water Environ. Manag. 7, 507-512

Finke, P.A. Brus, D.J. Bierkens, M.F.P. Hoogland, T. Knotters, M. and F. de. Vries (2004). Mapping 
groundwater dynamics using multiple sources of exhaustive high resolution data, Geoderma, 123, 23-39.

Gautam SK, Sharma D, Tripathi JK, Singh SK, Ahirwar S. (2013). A study of the effectiveness of sewage treatment plants in Delhi region. Appl Water Sci. 3:57-65.

Gautam SK, Maharana C, Sharma D, Singh AK, Tripathi JK, Singh SK. (2015). Evaluation of groundwater quality in the Chotanagpur plateau region of the Subarnarekha river basin, Jharkhand State, India. Sustain Water Qual Ecol. 6:57-74.

Gautam SK, Singh AK, Tripathi JK, Singh SK, Srivastava PK, Narsimlu B, Singh P. (2016). Appraisal of surface and ground water of the Subarnarekha River Basin, Jharkhand, India: Using Remote Sensing, Irrigation indices and statistical techniques. In: Srivastva PK, Pandey PC, Kumar P, Raghubanshi AS HD, editor Geospatial Technol water resour Appl. Boca Raton, FL: CRC Press; p. 144-169.

Goovaerts P. (1999), Geostatistics in soil science, Stateof-the-art and perspectives, Geoderma, 89, 1-45.

Gupta, D. P., and S.J.P. Saharan (2009). Physiochemical analysis of ground water of selected area of Kaithal city (Haryana) India. Researcher, 1(2), 1-5.

IS: 10500 , Indian standards for drinking water, Bureau of Indian Standards N. Delhi, India. 1991, 1-9, 179182.

Istok, J.D. and R.M. Cooper (1998). Geostatistics Applied to Groundwater Pollution. III: Global Estimates. Journal of Environmental Engineering, 114 (4), 915-928.

Jacintha TGA, Rawat KS, Mishra A, Singh SK. (2016). Hydrogeochemical characterization of groundwater of peninsular Indian region using multivariate statistical techniques. Appl Water Sci.:1-13.

Johanssion P. O. (1988). Methods for natural groundwater recharge directly from precipitationcomparative studies in sandy till. In Simmers I. ed., Estimation of Natural Groundwater Recharge. D. Reidel Publishing Company, Dordrecht, 239-270.

Kumar, A., Shahi, U.P., Dhyani, B.P., Naresh, R.K., Singh, B., Kumar, Y. and S. Sardar (2011). Quality assessment of groundwater in PMDEtreated farmland for drinking purpose. Plant Arch. 11(1), 187-191

Kumar RP, Ranjan RK, Ramanathan AL, Singh SK, Srivastava PK. (2015). Geochemical modeling to evaluate the mangrove forest water. Arab J Geosci. 8:4687-4702.

Lloyd, J.W.,Heathcote, J.A, (1985). Natural inorganic hydrochemistry in relation to groundwater an introduction.Clarendon Press; New York : Oxford University Press.

Mehrjardi, T.R., Jahromi, Z.M., and S.H.A. Mahmodi (2008). Spatial distribution of groundwater quality with geostatistics (case study: Yazd-Ardakan Plain).
World Applied Science Journal, 4, 9-17.

McCarthy M. F. (2004). Should we restrict chloride rather than sodium, Medical Hypotheses, 63: 138148.

NazariZade, F. F. Z. Arshadiyan, and K. BehnazVakily (2006),.Study of spatial variability of Groundwater quality of Balarood Plain in Khuzestan province", The first congress of optimized exploitation from water source of Karoon and Zayanderood Plain. University of Shahrekord, Persian Version, 2006, pp. 1236-1240.

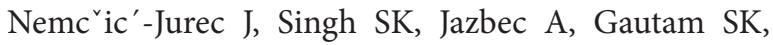
Kovac I. (2017). Hydrochemical investigations of groundwater quality for drinking and irrigational purposes: two case studies of Koprivnica-Kriz evci County (Croatia) and district Allahabad (India) Sustain. Water Resour. Manag. doi 10.1007/s40899017-0200-x

Olayinka K. O. (2004). Studies on industrial pollution in Nigeria: The effect of textile effluents on the quality of groundwater in some parts of Lagos. Nigerian Journal of Health and Biomedical Sciences, 3, 4450.

Phiri, O., Mumba, P., Moyo, B. H. Z. and W. Kadewa (2005). Assessment of the impact of industrial effluents on water quality of receiving rivers in urban areas of Malawi, International Journal of Environ. Sci. Tech, 2(3): 237-244.

Palanivelu, K., Priya, M.N., Selvan, A.M., U. Natesan (2006). Water-quality assessment in the tsunamiaffected coastal areas of Chennai. Current Science, 91, 15-20.

Rawat, K.S., Mishra, A.K., Sehgal, V.K., and V.K. Tripathi (2012a). Spatial Variability of Ground Water Quality in Mathura District (Uttar Pradesh, India) with Geostatistical Method.International Journal of Remote Sensing Applications, 2(1), 1-9.

Rawat, K.S., Mishra, A.K. and V.K. Sehgal (2012b). Identification of Geospatial Variability of Fluoride contamination in Ground Water of Mathura District, Uttar Pradesh, India.Journal of applied and Natural Science, 4(1), 117-122.

Rawat, K.S. and V.K. Tripathi (2015). Hydro-chemical Survey and quantifying Spatial variation of groundwater quality in Dwarka, sub-city of Delhi, India. Journal of the Institution of Engineers (India): Series A, DOI 10.1007/s40030-015-0116-0.

Rawat KS, Tripathi VK, Singh SK. (2017a). Groundwater quality evaluation using numerical indices: a case study (Delhi, India). Sustain. Water Resour. Manag. doi 10.1007/s40899-017-0181-9

Rawat KS, Mishra AK, Singh SK. (2017b). Mapping of groundwater quality using Normalized Difference Dispersal Index of Dwarka sub-city at Delhi National Capital of India. ISH J Hydraul Eng. 5010:1-12.

Rawat KS, Singh SK, Jacintha TGA, Nemc ${ }^{2} i c^{\prime}$-Jurec J, Tripathi VK. (2018). Appraisal of long-term 
groundwater quality of peninsular India using water quality index and fractal dimension. J. Earth Syst. Sci. doi. 10.1007/s12040-017-0895-y

Rawat, K.S. and S.K. Singh (2018). Water Quality Indices and GIS-based evaluation of a decadal groundwater quality, Geology, Ecology, and Landscapes, DOI: 10.1080/24749508.2018.1452462.

Safari M. (2002). Determination filtration network of Groundwater using geostatistic method, M.ScThesis.UniversityofTarbiyatModares, Agricultural Faculty, Persian Version.

Sánchez-Pérez, J.M. and M. Trémolières (2003). Change in groundwater chemistry as a consequence of suppression of floods: the case of the Rhine floodplain. J. Hydrol, 270, 89-104.

Srivastava PK, Singh SK, Gupta M, Thakur JK, Mukherjee S. (2013). Modeling impact of land use change trajectories on Groundwater quality using Remote Sensing and GIS. Environmental Engineering and Management Journal. 12:12, 2343-2355.

Singh SK, Basommi, BP, Mustak Sk, Srivastava PK, Szabo S. (2017). Modeling of land use land cover change using earth observation data-sets of Tons River Basin, Madhya Pradesh, India. Geocarto Int. 1-21. doi.org/10.1080/10106049.2017.1343390

Singh SK, Srivastava PK, Singh D, Han D, Gautam SK, Pandey AC. (2015). Modeling groundwater quality over a humid subtropical region using numerical indices, earth observation datasets, and X-ray diffraction technique: a case study of Allahabad district, India. Environ Geochem Health. 37:15780.

Singh SK, Srivastava PK, Pandey AC, Gautam SK. (2013a). Integrated assessment of groundwater influenced by a confluence river system: concurrence with Remote Sensing and Geochemical Modelling. Water Resour Manag. 27:4291-4313.

Singh SK, Srivastava PK, Pandey AC. (2013b). Fluoride contamination mapping of groundwater in Northern India integrated with geochemical indicators and GIS. Water Sci Technol Water Supply. 13:1513-1523.

Singh SK, Srivastava PK, Gupta M, Mukherjee S. (2012). Modeling mineral phase change chemistry of groundwater in a rural-urban fringe. Water Sci Technol. 66:1502-1510.

Singh SK, Singh CK, Mukherjee S. (2010). Impact of land-use and land-cover change on groundwater quality in the Lower Shiwalik hills: a remote sensing and GIS based approach. Cent Eur J Geosci. 2:124131.

Thakur J, Singh P, Singh SK, Baghel B. (2013). Geochemical modeling of Fluoride concentration in hard rock terrain of Madhya Pradesh, India. Acta Geol Sin (English Ed.) 87:1421-1433.

Thakur JK, Diwakar J, Singh SK. (2015). Hydrogeochemical evaluation of groundwater of Bhaktapur Municipality, Nepal. Environ Earth Sci. 74:4973-4988.

Trivedi, R.K., P.K. Goel (1986). Chemical and Biological Methods for Water Pollution Studies, Environmental Publication, Karad, 1-112.

Technical Report Series (2008). District Groundwater Brochure Chennai District Tamil NadubyBalakrishnan, T.,Government of India Ministry of Water Resources Central Ground Water Board South Eastern Coastal Region Chennai November 2008

World Health Organization (WHO), Guidelines for drinking water quality, 2nd edition. Geneva, World Health Organization, 1993, pp. 1-3. 